OPEN ACCESS

Edited by:

Quan Cheng,

Central South University, China

Reviewed by:

Zhijun Zhou,

University of Oklahoma Health

Sciences Center, United States

Wen-Jing Zeng,

Central South University, China

*Correspondence:

Tao Jiang

taojiang1964@163.com

Wei Zhang

zhangwei_vincent@126.com

Specialty section: This article was submitted to

Cancer Immunity and Immunotherapy,

a section of the journal

Frontiers in Oncology

Received: 31 July 2021 Accepted: 08 October 2021 Published: 26 October 2021

Citation:

Pan C, Zhai Y, Li G, Jiang T and Zhang W (2021) NK Cell-Based Immunotherapy and Therapeutic

Perspective in Gliomas.

Front. Oncol. 11:751183. doi: 10.3389/fonc.2021.751183

\section{NK Cell-Based Immunotherapy and Therapeutic Perspective in Gliomas}

\author{
Changqing Pan ${ }^{1}$, You Zhai ${ }^{2}$, Guanzhang $\mathrm{Li}^{2}$, Tao Jiang ${ }^{1,2,3,4^{*}}$ and Wei Zhang ${ }^{1,2,3,4 *}$ \\ ${ }^{1}$ Department of Neurosurgery, Beijing Tiantan Hospital, Capital Medical University, Beijing, China, ${ }^{2}$ Beijing Neurosurgical \\ Institute, Capital Medical University, Beijing, China, ${ }^{3}$ China National Clinical Research Center for Neurological Diseases, \\ Beijing, China, ${ }^{4}$ Chinese Glioma Genome Atlas (CGGA) and Asian Glioma Genome Atlas (AGGA), Beijing, China
}

Glioma is the most common malignant primary brain tumor diagnosed in adults. Current therapies are unable to improve its clinical prognosis, imposing the need for innovative therapeutic approaches. The main reason for the poor prognosis is the great cell heterogeneity of the tumor and its immunosuppressive microenvironment. Development of new therapies that avoid this immune evasion could improve the response to the current treatments. Natural killer (NK) cells are an intriguing candidate for the next wave of therapies because of several unique features that they possess. For example, NK cellbased immunotherapy causes minimal graft-versus-host disease. Cytokine release syndrome is less likely to occur during chimeric antigen receptor (CAR)-NK therapy, and CAR-NK cells can kill targets in a CAR-independent manner. However, NK cell-based therapy in treating glioma faces several difficulties. For example, CAR molecules are not sufficiently well designed so that they will thoroughly release functioning NK cells. Compared to hematological malignancies, the application of many potential NK cellbased therapies in glioma lags far behind. Here, we review several issues of NK cells and propose several strategies that will improve the efficacy of NK cell-based cancer immunotherapy in the treatment of glioma.

Keywords: natural killer cells, alloreactivity, chimeric antigen receptor, adoptive cell immunotherapy, glioma

\section{INTRODUCTION}

Gliomas are the most common intracranial primary malignant tumor (1). The incidence of gliomas is approximately of six cases per 100,000 individuals worldwide. Glioblastoma (GBM), the most common glioma histology, has a 5 -year relative survival of $\sim 5 \%$. While the majority of cases are sporadic, a small portion of these tumors are associated with neurofibromatosis type I, tuberous sclerosis, and Li-Fraumeni syndrome. Standard medical care, including the most extensive tumor resection followed by radiotherapy and chemotherapy. Surgery is commonly performed with both diagnostic and therapeutic intent. The therapeutic goal of surgery is to remove as much tumor tissue while preserving neurological function. Even for diffuse gliomas, a biopsy is recommended to acquire tissue specimens for molecular profiling (IDH mutations, $1 \mathrm{p} / 19 \mathrm{q}$ codeletion, MGMT promoter methylation, EGFR amplification et al) (2). Most patients receive chemotherapy. Classic schemes including Stupp (NCT00006353) and PCV (Procarbazine, CCNU, and Vincristine) (3). The strategies of radiotherapy are determined by the disease subtype and prognostic factors, including residual tumor volume, age, KPS. The details of novel strategies 
including tumor-treating fields (TTFields), checkpoint inhibitor, vaccine and oncolytic virus are described in Table 1. In general, the prognosis of high-grade glioma is still unpleasant, which calls for more efficient approaches.

Adoptive cell therapy (ACT), especially CAR-armed cell therapy, has great potential due to its high cytotoxicity and precise strikes. ACT consists of a series of infusions of autologous or allogeneic immune cells to kill targets, and $\mathrm{T}$ cell-based immunotherapy is an example of a mainstream form of ACT that is well-studied. Chimeric antigen receptor (CAR) T cells targeting CD19 is one therapy that has resulted in encouraging success in patients with B cell malignancies and has been approved by the US Food and Drug Administration (FDA) (5$7)$. However, there are numerous logistic and clinical limitations to the use of autologous CAR-modified T cells. Personalized CAR-T products are time-consuming and expensive to produce. Allogeneic $\mathrm{T}$ cell-based therapy can cause substantial toxic effects, such as graft-versus-host disease (GvHD) and cytokine release syndrome (CRS) (8). Furthermore, the results of CAR-T cell therapy for solid tumors are suboptimal. These shortcomings of CAR-T cells have called for interest in other candidate.

NK cells are a subpopulation of the innate immune system ( 9 , 10). NK cells can be identified by CD3(-) CD56(+). Depending on the level of CD56 and CD16 expression, NK cells can be divided into $\mathrm{CD} 16^{+} \mathrm{CD} 56^{\mathrm{dim}}$ and $\mathrm{CD} 16^{-} \mathrm{CD} 56^{\text {bright }}$ cells. $\mathrm{CD} 16^{+} \mathrm{CD} 56^{\mathrm{dim}} \mathrm{NK}$ cells predominate in peripheral blood while $\mathrm{CD} 16^{-} \mathrm{CD} 56^{\text {bright }} \mathrm{NK}$ cells are distributed into secondary lymphoid organs (11). $\mathrm{CD}^{-} 6^{-} \mathrm{CD} 56^{\text {bright }} \mathrm{NK}$ cells are robust cytokine producers and are weakly cytotoxic while the $\mathrm{CD} 16^{+} \mathrm{CD} 56^{\mathrm{dim}} \mathrm{NK}$ cell population can mediate serial killing of infected and/or malignant cells. NK cell receptors are germline-encoded without a requirement for ' $V(D) J$ ' recombination. Natural killer (NK) cells have gained attention as a promising alternative candidate for ACT owing to their unique biological attributes.

NK cells do not require any prior antigen and can rapidly recognize and kill cells for which major histocompatibility complex (MHC) class I molecular expression is compromised by infection or transformation (9). Once activated, NK cells can release perforin and granzyme, contributing to target cell lysis. NK cells upregulate death ligands on their surface, such as FAS ligand and TRAIL, and initiate the caspase pathway of tumor cells and induce apoptosis when binding to death receptors on target cells. NK cells can eradicate cancer cells through antibodydependent cellular cytotoxicity (ADCC) mediated by Fc $\gamma$ RIIIA/ CD16a. Furthermore, NK cells produce interferon gamma (IFN- $\gamma$ ), regulating and activating the adaptive immune response.

NK cell-based therapy is safe and has potential generated as off-the-shelf cellular therapy products. Autologous NK cells exert limited cytotoxicity against autologous tumors, while allogeneic NK cells are highly cytotoxic and cause minimal risk of GvHD (12-16). Thus, NK cells can originate from different sources, such as peripheral blood NK cells (PBNK), induced pluripotent stem cells (iPSCs), umbilical cord blood (UCB) and NK-92 cells, and this eliminates the need to produce a personalized CAR-NK product. However, the claim that allogeneic NK cells cause no or minimal GvHD and CRS is controversial and originated from observations obtained during clinical trials, especially in the setting of hematopoietic cell transplantation (HCT), the mechanism of which has not been thoroughly discussed. Here, we review important issues regarding NK cells and glioma and discuss several options that can be used to improve the efficacy of CAR-NK in glioma treatment.

\section{THE SAFETY OF NK CELL-BASED IMMUNOTHERAPY}

\section{NK Cell Alloreactivity}

All NK cells are non-responsive towards healthy autologous cells, which involves the interaction of at least inhibitory killer immunoglobulin-like receptors (KIRs) or CD94-NKG2A with one autologous MHC class I molecule. KIRs can be classified based on two factors: the number of immunoglobulin-like

TABLE 1 | Applications of novel strategies in glioma.

\begin{tabular}{|c|c|c|c|c|c|}
\hline Strategies & Interventions & Results & Tumors & Phase & $\begin{array}{l}\text { Reference/ } \\
\text { NCT }\end{array}$ \\
\hline TTFields & $\begin{array}{l}\text { TTFields plus temozolomide VS } \\
\text { temozolomide alone }\end{array}$ & TTFields plus temozolomide improve PFS and OS significantly & Glioblastoma & III & NCT00916409 \\
\hline \multirow[t]{2}{*}{$\begin{array}{l}\text { Checkpoint } \\
\text { Inhibitor }\end{array}$} & nivolumab VS bevacizumab & Nivolumab failed to improve OS & $\begin{array}{l}\text { Recurrent } \\
\text { Glioblastoma }\end{array}$ & III & NCT02017717 \\
\hline & Neoadjuvant pembrolizumab & $\begin{array}{l}\text { Neoadjuvant extended OS and enhanced both the local and } \\
\text { systemic antitumor immune response }\end{array}$ & $\begin{array}{l}\text { Recurrent } \\
\text { Glioblastoma }\end{array}$ & / & $\begin{array}{l}\text { Cloughesy } \\
\text { et al. (4) }\end{array}$ \\
\hline \multirow[t]{3}{*}{ Vaccine } & $\begin{array}{l}\text { Rindopepimut (CDX-110), a vaccine } \\
\text { targeting EGFRvIll }\end{array}$ & Rindopepimut did not increase OS & Glioblastoma & III & NCT01480479 \\
\hline & $\begin{array}{l}\text { peptide vaccine (IDH1-vac) targeting } \\
\text { mutant IDH1 }\end{array}$ & $\begin{array}{l}\text { IDH1-vac increased PFS and immune responses, but accompanied } \\
\text { by a high frequency of pseudoprogression }\end{array}$ & $\begin{array}{l}\text { Grade III and IV } \\
\text { Astrocytomas }\end{array}$ & I & NCT02454634 \\
\hline & $\begin{array}{l}\text { autologous dendritic cell vaccine } \\
\text { ICT-107 }\end{array}$ & ICT-107 significantly improved PFS & Glioblastoma & $\|$ & NCT01280552 \\
\hline \multirow[t]{2}{*}{$\begin{array}{l}\text { Oncolytic } \\
\text { Virus }\end{array}$} & $\begin{array}{l}\text { intratumoral infusion of polio- } \\
\text { rhinovirus chimera (PVSRIPO) }\end{array}$ & PVSRIPO therapy increased OS & $\begin{array}{l}\text { Recurrent } \\
\text { malignant Glioma }\end{array}$ & I & NCT01491893 \\
\hline & $\begin{array}{l}\text { intratumoral injection of oncolytic } \\
\text { adenovirus (DNX-2401) }\end{array}$ & DNX-2401 resulted in dramatic responses with long-term survival & $\begin{array}{l}\text { Recurrent } \\
\text { malignant Glioma }\end{array}$ & 1 & NCT00805376 \\
\hline
\end{tabular}


domains (2D and 3D) and the length of the intracytoplasmic tail (L or S). Inhibitory KIRs usually possess a long cytoplasmic tail (KIR2DL), whereas activating KIR possess a short one (KIR2DS), except for the activating KIR2DL4, which has a long cytoplasmic tail. Inhibitory KIRs contain immunoreceptor tyrosine-based inhibition motif (ITIM) sequences responsible for the inhibitory signal. Unlike cytotoxic CD8+ T cells, which are highly specific for antigens, NK cells express clonally distributed inhibitory receptors termed KIRs that recognize determinants (KIR ligands) shared by subsets of HLA-B or -C allotypes (17-20). More than fifty KIR family members have been identified, and each of these genes is highly polymorphic and has thousands of alleles (21). Three subfamilies and associated inhibitory specificities are well determined (Table 2). The CD94-NKG2A heterodimer, belonging to Ctype lectins, is specific for HLA-E (24-26).

Major models used to predict NK cell alloreactivity include 'missing self and 'missing ligand' (Figure 1). Missing selfrecognition (the 'ligand-ligand' model) was proposed by Karre

TABLE 2 | Three subfamilies of KIRs and specific ligands.

\begin{tabular}{ll}
\hline Group $^{\mathbf{a}}$ & HLA-class I specificity $^{\mathbf{b}}$ \\
\hline KIR2DL1(CD158a) & $\mathrm{C} 2(-\mathrm{Cw} 2,-\mathrm{Cw} 4,-\mathrm{Cw} 5,-\mathrm{Cw6})$ \\
KIR2DL2/3(CD158b1/b2) & $\mathrm{C1}(-\mathrm{CW} 1,-\mathrm{Cw} 3,-\mathrm{CW} 7,-\mathrm{Cw} 8)$ \\
KIR3DL1(CD158e1) & Bw4(-B27, -B51)
\end{tabular}

${ }^{a}$ Each group compromises different numbers of alleles, which differ by 1-9 nucleotide substitutions (22).

${ }^{b}$ Two groups of HLA-C alleles are distinguished by dimorphic positions Ser 77-Asn 80 (C1) and Asn 77-Lys 80 (C2) of the $\alpha 1$ helix (23). HLA-B allotypes share the Bw4 sequence motif at positions $77-83$ of the $\alpha 1$ helix (22). et al. and occurs under HLA haplotype-mismatched transplants in the graft-versus-host direction (27). Donor NK cells express a KIR for the self HLA class I group that is absent in the recipient, which mediates alloreactions (28-30). HLA testing is required to predict NK cell alloreactivity due to the missing self-model.

Because the genes for KIR, HLA, and CD94-NKG2 are located on different chromosomes (31-33), KIR genes segregate independently of the HLA genes, and thus, KIR mismatches can exist in two HLA-matched individuals. Also, it was found that many individuals have 3 inhibitory KIRs (for HLA-C1 and -C2 and for HLA-Bw4 alleles), while their own cells only express 1 or 2 HLA KIR ligands $(22,34,35)$. KIR expression is donor specific, but not related to the donor or recipient HLA and is not affected by the recipient's HLA groups (36). The missing ligand model (the 'receptor-ligand' model) was based on these. According to this model, NK cell alloreactivity occurs not only in HLA haplotypemismatched transplants, but also in HLA haplotype-matched transplants from donors possessing 'extra' $\mathrm{KIR}(\mathrm{s})$, for which neither donor nor recipient possess HLA ligand(s) (35-37). The donor's potentially self-reactive NK cells can trigger an alloreactive effect in the recipient while maintaining anergy in the donor. Analysis of the KIR expression on the donor's NK cells and HLA testing of the recipient's cells are required to predict NK cell alloreactivity due to the missing ligand model.

The missing self and missing ligand models can be used to predict NK cell alloreactivity. Although alloreactive NK cells can eradicate tumor cells, the anti-tumor effect is not confined to alloreactive NK cells. NK cell activity depends on the balance between inhibitory and stimulatory receptors. An anti-tumor effect can be mediated by NK cells expressing stimulatory receptors, such as activating KIR and NKG2D (38-40).

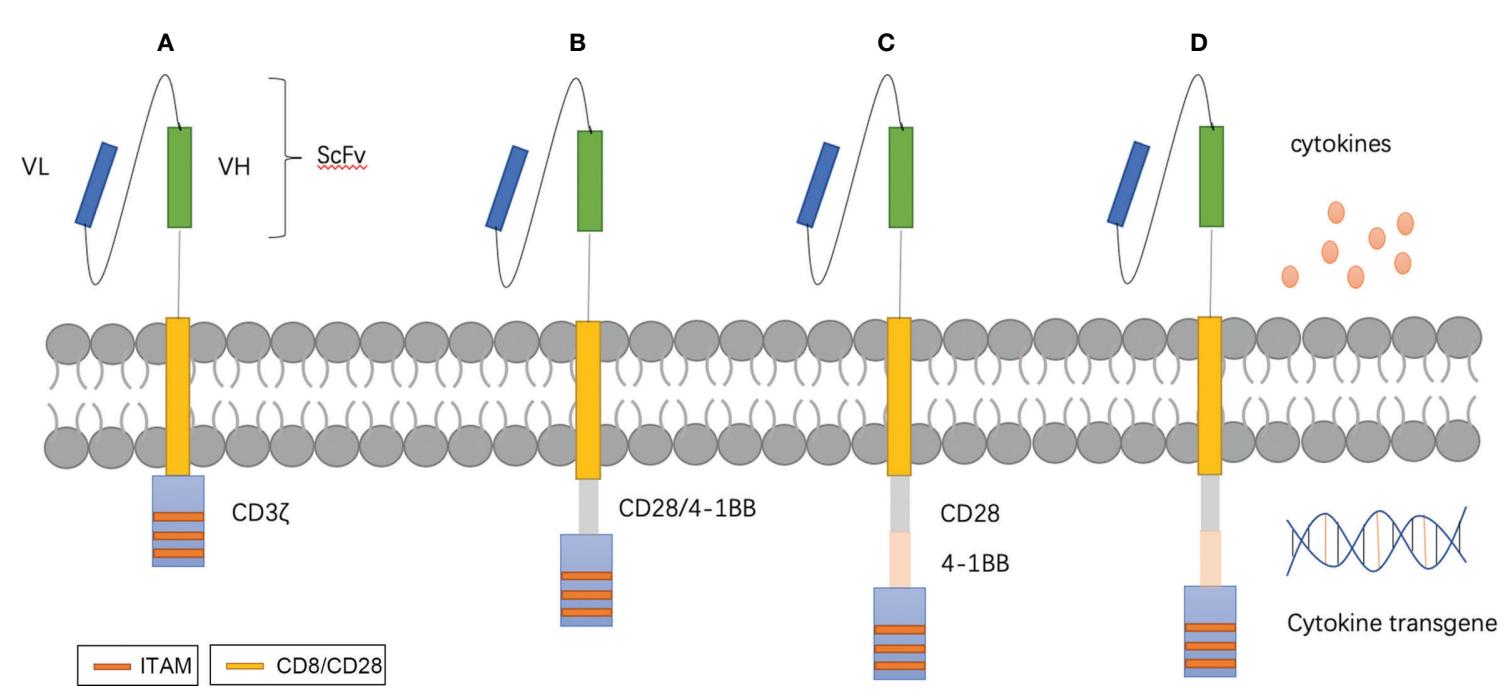

FIGURE 1 | T-CAR designs. (A-D) show the four generations of T-CAR. In brief, CAR contains three parts: extracellular domains are comprised of a single-chain variable fragment (scFv) for recognizing targeted antigen and transmembrane domains, and endocellular domains for transducing signals. First generation CARs

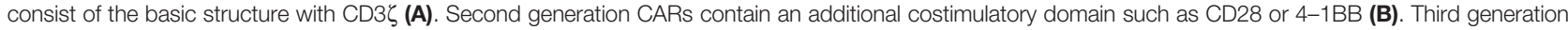
CARs possess multiple costimulatory domains (C). Fourth-generation CARs, also known as 'armored CARs' can be designed to secret cytokines to improve the proliferation, persistence. 


\section{NK CELL-BASED IMMUNOTHERAPY CAUSES MINIMAL GvHD AND CRS}

GvHD refers to a condition resulting from the systemic attack of allogenic $\mathrm{T}$ cells on recipient tissues after allogeneic hematopoietic stem cell transplantation or infusion of allogeneic $\mathrm{T}$ cells (41-43). The effects of GvHD are commonly manifested in the gastrointestinal tract, liver, and skin (44), and severe GvHD can be fatal. The role of alloreactive NK cells on GvHD in the setting of HCT varies among studies. Some investigations found that alloreactive NK cells were related to decreased GvHD $(36,45,46)$, which was partially attributed to the observations that allogeneic NK cells would be expected to kill host dendritic cells (DCs) and donor T cells $(46,47)$. Miller et al. analyzed 2,062 patients undergoing unrelated donor HCT (48). They found that one or more KIR ligands were missing versus the presence of all ligands, which is associated with a low relapse rate in patients with early myeloid leukemia. This omission predicted a greater risk of developing grade 3-4 GvHD in the setting of chronic myeloid leukemia (CML) patients. Miller et al. attributed the higher rate of acute GvHD in CML to the expanded myeloid pool with more host antigenpresenting cells (APCs) capable of presenting alloantigen to donor $\mathrm{T}$ cells (48).

HCT after ablation of bone marrow is used to cure hematological malignancies and results in less cancer relapse compared to chemoradiotherapy (49). T cells of allogeneic hematopoietic grafts for treating leukemia mediate the antileukemia effect as well as lethal GvHD. In many studies, it was attempted to prevent GvHD by depleting the $\mathrm{T}$ cells from the graft and infusing large numbers of hematopoietic stem cells to overcome rejection (50), which was at the expense of immunity reconstitution failure and infection. Later, NK cells from alloreactive donors were found to protect patients against rejection and GvHD in the setting of HCT (46). Interestingly, we found the idea that NK cell-based therapy caused GvHD mostly happened in the setting of HCT. But we should not evaluate the effects of alloreactive NK cells on GvHD in the setting of HCT because the effect of T cells in the grafts is negligible. It is likely that $\mathrm{T}$ cell interference is the most important controversial element with respect to the alloreactive NK cell effects on GvHD.

In fact, NK cell-based immunotherapy is safe and causes minimal GvHD. GvHD most likely occurs when NK cells from donors with several KIR subfamilies are infused into recipients possessing one group HLA ligand. Valiante et al. analyzed NK cell receptor repertoires in the peripheral blood of two human donors (donor PP only possessed group 1 HLA-C ligand, and donor NV possessed group 1 and 2 HLA-C ligands and the Bw4 HLA-B ligand, both of which have three KIR subfamilies as demonstrated in Table 2) (51). They found that more than 98\% of NK clones were inhibited self-HLA class I allotypes, and no NK cell from either donor was able to lyse the autologous B cell line (51). Interestingly, NV possessed approximately $15 \%$ of the analyzed NK cell clones, did not express KIR2DL2 or CD94: NKG2a, and was able to lyse the B cell line from PP, whereas the
NK cell clones from PP failed to lyse the B cell line from NV (51). Ruggeri adopted functional analysis to evaluate the NK cell alloreactivity in more than $200 \mathrm{NK}$ clones (46). Alloreactivity was defined as positive when the frequency of lytic clones was no less than 1 in 50 (46). In addition, the expression of CD94: NKG2a is inversely related to KIR levels (51). Approximately, $50 \%$ of NK cells in an individual express CD94:NKG2a $(51,52)$. Cell-surface HLA-E expression depends on many peptides, including the leader peptides of HLA-A, $-\mathrm{B}$, or $-\mathrm{C}$, and downregulation of HLA-E expression requires the elimination of three types of HLA molecules $(53,54)$. Thus, NK cells expressing CD94-NKG2A display no alloreactivity because all individuals express HLA-E molecules. Therefore, NK cell-based immunotherapy is safe most of the time and will cause minimal GvHD because alloreactive NK cells only account for a small proportion. In addition, healthy cells express high levels of MHC class I molecules, but they express no or minimal level of ligands for NK cell activating receptors. Conversely, tumorigenic cells downregulate MHC class I expression but upregulate the expression of ligands for NK cell activating receptors. For example, MICA/MICB and ULBP, ligands for NKG2D, are often induced by stress or transformation $(55,56)$. The integration of the activating and inhibitory signals from the ligand/receptor determines NK cell activity. Some studies indicated that the positive signal delivered by NKG2D could override inhibition. Therefore, NK cells become alloreactive prior to killing tumor cells.

CRS involves elevated levels of circulating cytokines, especially interferons and immune-cell hyperactivation, which manifests as an influenza-like syndrome, organ failure, and even death (57). CAR-NK is less likely to induce CRS and neurotoxicity partially because of a different spectrum of secreted cytokines consisting of activated NK cells that produce IFN-gamma and GM-CSF, and CAR-T cells that predominantly release tumor necrosis factor (TNF)-a and interleukins, such as IL-1, IL-2, and IL-6 $(57,58)$. The mechanism was validated by clinical trials. Liu et al. launched a clinical trial (NCT03056339) that administered HLA-mismatched anti-CD19 CAR-NK cells to 11 patients with high-risk lymphoid malignancies (16). The administration of CAR-NK cells was not associated with the development of cytokine release syndrome and there was no increase in the levels of inflammatory cytokines, including interleukin-6, over baseline (16).

\section{NK EXPANSION TECHNIQUES}

Large numbers of cells are essential for successful adoptive transfer cell therapy. It has been proved that high doses of NK cells from $10^{\wedge} 7$ cells $/ \mathrm{kg}$ to $4.7 \times 10^{\wedge} 10$ total NK cells can be well tolerated $(16,59,60)$. NK cells only account for approximately $10 \%$ of peripheral blood mononuclear cells. The NK92 cell line is used in current clinical trials with CAR-NK because of their unlimited proliferation ability in vitro. However, the NK92 cell line is tumorigenic and lacks CD16 and NKp44 expression, and additionally, these cells will lose their proliferation ability due to 
lethal irradiation infusion $(61,62)$. Because of these drawbacks, it is unlikely that they will be an ideal cell source for CAR-NK cell therapy.

Expansion protocols possess considerable heterogeneity. The expansion process often takes 2-3 weeks of culture in the presence of mitogenic cytokines, and engineered feeder cells can optimize the expansion process. K562 cells engineered to express membrane-bound IL-15 or IL-21 along with the adhesion molecule 4-1BBL are adopted as feeder cells in many clinical trials $(63,64)$. There have been reports of 300 -fold expansions combined with IL-2 and IL-15. IL-15 is important to NK cell survival and function $(65,66)$, and $4-1 \mathrm{BBL}$ provides a cell to cell contact-dependent co-stimulatory signal (67). We observed that low density less than $10^{\wedge} 5 \mathrm{cell} / \mathrm{s} / \mathrm{mL}$ is not ideal for $\mathrm{NK}$ expansion. We recommend that the ratio of engineered $\mathrm{K} 562$ feeder cells and NK cells is 1:1 to 2:1. The K562 cell line possesses unique properties and lacks HLA expression. As described above, inhibitory KIRs recognizing corresponding HLA ligands can inactivate NK cells. This can be proved by our laboratory findings that other cell lines engineered to express IL-21 and 41BBL failed to achieve high-fold NK expansion. Some studies used RetroNectin-stimulated T (RN-T) cells as feeder cells (68, 69). Briefly, the procedure for this is to culture $T$ cells from autologous peripheral blood mononuclear cells (PBMCs) with RetroNectin and anti-CD3 monoclonal antibody. In approximately 2 weeks, RN-T cells can serve as feeder cells after irradiation. RetroNectin plays a role in cell adhesion (70). The anti-CD3 monoclonal antibody leads to T-cell activation and cytokine secretion, and activated $\mathrm{T}$ cells express ligands of NKG2D $(47,71)$. Irradiated PBMCs as feeder cells were utilized by Parkhurst et al. and share a similar mechanism with RN-T in NK cell expansion $(60,72)$. The CD14+ monocyte fraction of irradiated PBMCs function in cell-cell contact (73). Feeder cells derived from autologous PBMCs eliminate the need for infusion of viable malignant feeder cells into the NK cell product. Feederfree expansion approaches have also been tested. Li et al. cultured NK cells in an anti-CD16 (Beckman Coulter)-coated flask (74). Antibody-coated beads targeting CD2 and NKp46 (CD335) are commercially available. However, not everyone or each NK cell expresses these stimulatory receptors, and feeder-free expansion protocols lose cell-to-cell contact effects. For example, only a part of NK cells of an individual expresses CD16 on blood NK cells $(75,76)$.

\section{ADOPTIVE CELL THERAPY AND CAR-NK CELLS}

There are several developmental stages in ACT. Lymphokineactivated killer (LAK) cells, which consist of a mixture of NK cells, NKT cells, and T cells, were adopted to overcome insufficient quantities of immune cells (77). An unwanted side effect of a high dose of IL-2 is that it induces capillary leak syndrome and neuropsychiatric diseases in a manner similar to that of CRS. To obtain immune cells that can effectively respond to tumors, Rosenberg introduced the concept of tumor- infiltrating lymphocytes (TILs) (78), which have many similarities with LAK cells except the origin of lymphocytes. The former is isolated from the stroma of tumors, while the latter is acquired from PBMCs. Success with TILs has been achieved in many solid tumors, including breast cancer tumors $(79,80)$. With TCR engineering, tumor-specific TCR $\alpha$ and $\beta$ chains are identified and integrated with T cells via viral vectors (81). There must be specificity with T-cell engineering and CAR-T. Compared to CAR-T therapy, there are limited choices for physiological receptors with TCR engineering. Effective CAR-T cell therapy relies on optimal CAR molecular design. The CAR construct is becoming increasingly sophisticated with the understanding of $\mathrm{T}$ cell activation and tumor-specific and -associated antigens (82). Four generations of CAR designs have been developed that are mainly different in categories and number of co-stimulation factors (Figure 1). For safety and effectiveness, many novel designs have been tested, such as 'inverted CAR,' 'off-switch CAR' and 'logic-gate CAR' (83-85).

NK cell-based immunotherapy is a subset of ACT and is similar to adoptive $\mathrm{T}$ therapy, especially with respect to CAR therapy. CAR-NK-related clinical trials show that the most adopted CAR design corresponds with first and second generation T-CAR (86). Most NK-CARs use CD28 and 4-1BB, which are more specific to $\mathrm{T}$ cells, as their transmembrane and intracellular domain, respectively $(87,88)$. Later studies began to design CARs specific to NK cells. For example, intracellular domains replaced CD28 with 2B4, DAP12, or DAP10 $(89,90)$. $\mathrm{Li}$ et al. proved that the signaling domains of CAR-NK, such as NKG2D-2B4, exhibited superior in vitro and in vivo anti-tumor activities compared to that which contains CD28-4-1BB (91). The revolution of CAR-NK therapy is described in Figures 2A-D, and it is clear that the CAR construct is becoming increasingly sophisticated with the growing understanding of $\mathrm{T}$ cell activation and tumor-specific and -associated antigens that are also suitable for NK cells.

\section{IMMUNOSUPPRESSIVE MECHANISMS OF GLIOMA}

Glioma, especially GBM, shows an extreme cell heterogeneity, diffuse growth patterns and high invasiveness. Gliomas were thought to be "immune cold" tumors with low infiltration of lymphocytes (95). Furthermore, microenvironment of the glioma has the ability to suppress immune response systematically and locally.

Mahaley et al. first reported the presence of lymphopenia in GBM (96). Studies have found patient-derived peripheral blood lymphocytes shows immune defects that exhibited varying levels of proliferative unresponsiveness to the T-cell mitogens concanavalin A (ConA), phytohemagglutinin (PHA) and anti-CD3 monoclonal antibody as well as with the T-dependent B-cell mitogen, pokeweed mitogen (PWM) $(97,98)$. A selective impairment of the IL-2 system and T cell receptor-mediated signaling in lymphocytes of patients with glioblastomas may contribute to the unresponsiveness $(99,100)$. Compared to healthy individuals, 


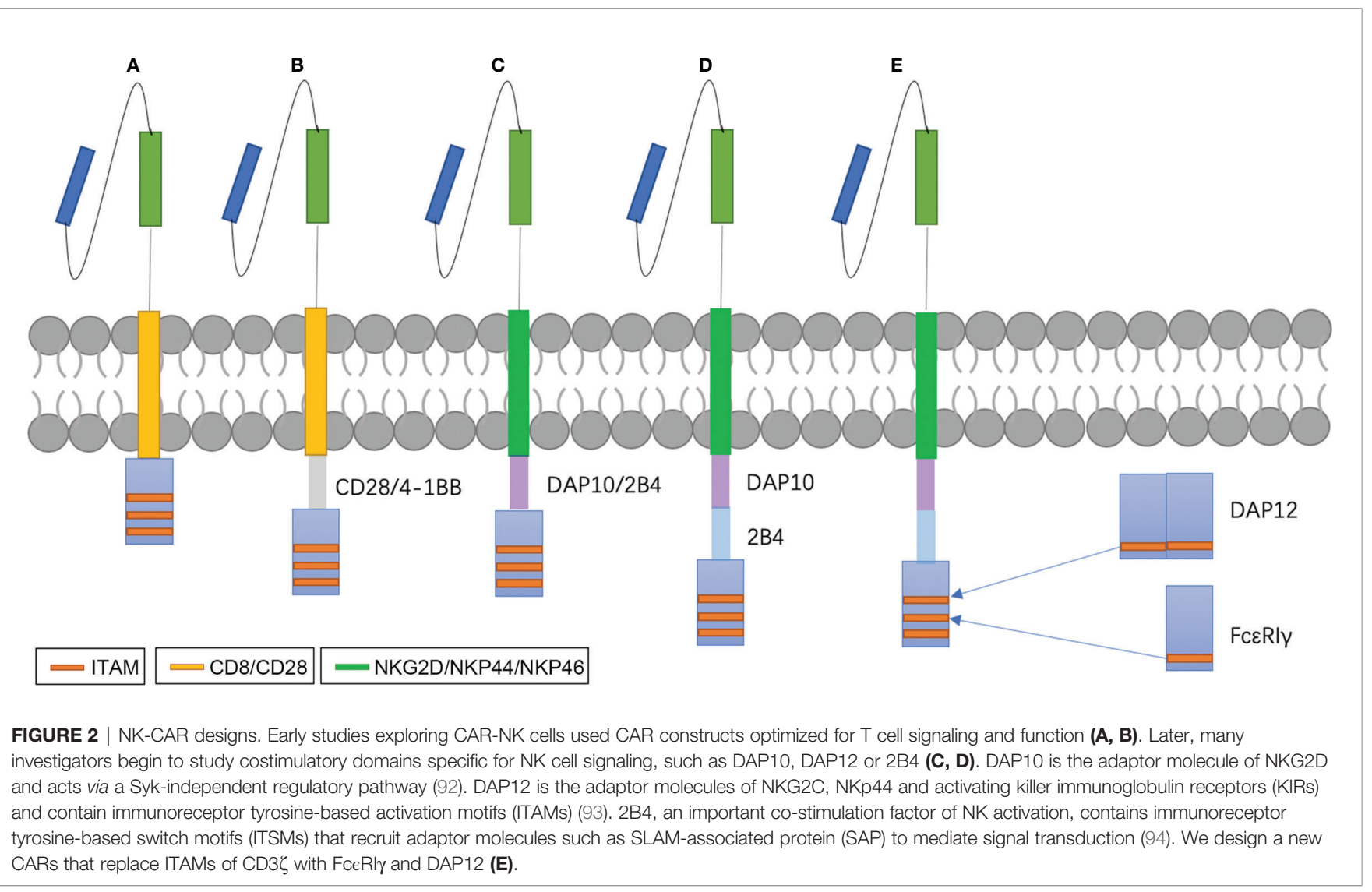

accumulation of myeloid-derived suppressor cells (MDSCs) in the peripheral blood of patients with glioma was found $(101,102)$. MDSCs impair tumor immunity by interacting with macrophages to increase IL-10 and decrease IL-12 production, driving a tumorpromoting type 2 response (103). Inhibitory soluble factors secreted by glioma can suppress lymphocyte's function. Transforming growth factor beta (TGF- $\beta$ ) can impair peripheral blood NK cell function by downregulating NKG2D (104-107). Therefore, the immune responses are suppressed systematically in glioma microenvironment.

Gliomas often overexpress phosphorylated signal transducer and activator of transcription 3 (p-STAT3) that induces a variety of immunosuppressive factors including IL-10, prostaglandin E2 (PGE2), vascular endothelial growth factor (VEGF) and TGF- $\beta$ (108). These soluble factors can suppress cytotoxic T lymphocytes activity and proliferation (108). TGF- $\beta$ and IL-10 can induce Tregs that inversely modulate immune response (109). Chemokines and cytokines, such as CX3CL1 and CCL5 can recruit tumorassociated macrophages to GBM microenvironment and contribute to abnormal angiogenesis $(110,111)$. Most GBM cells express high levels of MHC class I molecules that can inhibit NK cells by interacting with inhibitory KIRs (112). Absolute survival advantages of tumor depriving of nutrition and oxygen might suppress NK cell metabolism and antitumor activity (113). N6methyladenosine (m6A) modification is an emerging field in the study of tumorigenicity and therapy resistance of glioma (114, 115). The relationship between m6A states and immune infiltration and function in glioma is still unclear. Studies found higher m6Ascore was associated with $\mathrm{T}$ cells exhaustion and lower NK cells in the m6Ascore-high pancreatic ductal adenocarcinoma (116). So, the immune responses are suppressed locally in glioma microenvironment.

\section{APPLICATIONS OF NK CELLS FOR GLIOMA TREATMENT}

Except for unique advantages of NK cells, there is still a potential of NK cells in treating glioma. Cózar et al. analyzed RNA-seq datasets from the TCGA database and found NK-cell infiltration in both low grade glioma and GBM and even had higher scores compared to T-cell infiltration, which paved the way for the use of treatments targeting NK cells in glioma (117). Similar to adoptive $\mathrm{T}$ therapy, NK cell-based immunotherapy mainly concentrates on hematological malignancies. Thus far, the therapeutic utility of NK cell-based immunotherapy for the treatment of glioma has mainly been investigated in preclinical studies (Table 3). These trials most utilize either PBNK cells or NK92 cells, as well as first and second generation CARs designed for T cells and not optimized for NK cell signaling. Furthermore, clinical trials pay more attention to evaluate the safety of CARNK therapy. Although preclinical studies began to test the efficiency of DAP12 specific for NK cell signaling. Most of 
TABLE 3 | Applications of NK cells in glioma.

\begin{tabular}{|c|c|c|c|c|c|}
\hline Targets & NK Source & CAR construct & Tumors & Phase & Reference/NCT \\
\hline EGFRvIII & NK92 cell line & scFv-CD28TM+IC-CD3 $\zeta$ & Glioblastoma & l & Genßler et al. (118) \\
\hline EGFRvIII & YTS NK cell line & scFv-DAP12 TM+IC & Glioblastoma & / & Müller et al. (90) \\
\hline EGFRvIII & KHYG-1 NK cell line & scFv-CD28 TM+IC-CD137-CD3ל & Glioblastoma & I & Murakami et al. (119) \\
\hline EGFRvIII & NK92 cell line & scFv-CD28 TM+IC-CD3 & Glioblastoma & / & Han et al. (120) \\
\hline HER2 & NK92 cell line & scFv-CD3 TM+IC & Glioblastoma & / & Alkins et al. (121) \\
\hline HER2 & NK92 cell line & scFv-CD28 TM+IC-CD3 $\zeta$ & Glioblastoma & / & Zhang et al. (122) \\
\hline HER2 & NK92 cell line & 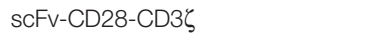 & Glioblastoma & 1 & NCT03383978 \\
\hline HER2 & NK92 cell line & Unknown & Glioblastoma & 1 & NCT03383978 \\
\hline MUC1 & Unknown & Unknown & High Grade Glioma & $|/| \mid$ & NCT02839954 \\
\hline None & PBMCs & None & High Grade Glioma & 1 & NCT04254419 \\
\hline None & PBMCs & None & Glioma & 1 & NCT00909558 \\
\hline None & Placenta & None & High Grade Glioma & 1 & NCT04489420 \\
\hline
\end{tabular}

them adopted similar CARs as used in clinical trials. Compared to hematological malignancies, both in the quantity and CARs design, the application of NK cell-based therapies in glioma lags far behind.

\section{FUTURE PERSPECTIVES}

Compared to T cell-based therapy, the development of NK cellbased therapy falls behind to some degree in the treatment of glioma. Adoptive NK cell therapy is lack of in vivo persistence without cytokine support, which may limit the efficacy of the NK cell immunotherapy. System administration of cytokines is associated with undesirable toxicities as described above. Trafficking to tumor beds is critical for the efficacy of adoptive cellular therapy. Müler et al. observed an infiltration increase of anti-EGFRvIII CAR-NK cells engineered to express CXCR4 to CXCL12/SDF-1 $\alpha$ secreting glioblastoma cells, leading to improved tumor regression and survival in a mouse model of glioblastoma (90). The difficulty may be resolved by intratumoral administration of NK cells products. In general, there is much room for the development of CAR-NK therapy in the field of glioma treatment. Much more pressing for NK cell-based therapy is designing more efficient products in treating glioma. Therefore, we try to put up several strategies to achieve the goal on the base of the knowledge of NK cells and glioma.

NK cell therapy is the lack of in vivo persistence in the absence of cytokine support. IL-15 is essential for NK cell function and homeostasis and can be added to CAR molecules to mimic the fourth generation of T-CAR. TGF- $\beta$ plays an essential role in impairing NK cell function. Inverted CAR may be applied to reverse the situation by fusing the ectodomain of the TGF- $\beta$ receptor to the endodomain of an activating receptor. $\mathrm{CD} 3 \zeta$ is found in the intracellular domains of T-CAR and NK-CAR. Furthermore, $\mathrm{CD} 3 \zeta$, containing three immunoreceptor tyrosinebased activation motifs (ITAMs; YxxL/Ix6-8YxxL/I, with 29 amino acids), has a limited impact on the effectiveness of CAR-NK (123).

Modification targeting $\mathrm{CD} 3 \zeta$ has been tested in CAR-T therapy. $\mathrm{Wu}$ et al. found that $\mathrm{CD} 3 €$ recruits Csk and p85 via its mono-phosphorylated ITAM and BRS motif, respectively (124). Incorporation of the ITAM of CD3e into a second- generation CAR increased the antitumor activity of CAR-T cells by reducing the cytokine production and promoting the persistence of CAR-T (124). NK cells possess many types of stimulatory receptors, such as CD16, NKp46, and NKG2D, and these stimulatory receptors do not act separately. In fact, apart from CD16, which is sufficient for activation of resting NK cells, it is necessary for all activating receptors to cooperate and synergize with one another for NK activation (125). Interestingly, the ITAM of many stimulatory receptors or their related adaptors, such as FceRI $\gamma$ and DAP12, also consists of 29 amino acids with different sequences. Therefore, an exchange may produce more effective CAR-NK cells (Figure 2E) with mild changes in $\mathrm{CD} 3 \zeta$ structure.

CAR-NK cells can kill targets in a CAR-independent manner. Combination therapy with monoclonal antibodies is promising, and it was observed that trifunctional antibodies recognized targets and simultaneously engaged NKP46 and CD16, which controlled tumor growth in mouse models (126). A team used antibodies to prevent the loss of cell surface MICA and MICB in human cancer cells, which stabilizes the bond between NKG2D and its ligands. These antibodies inhibit tumor growth in mouse models, and the antitumor effect is mediated mainly by the activation of NKG2D and CD16 (127). Apart from the activating receptors, antibodies blocking the inhibitory receptors of NK cells, such as KIR, NKG2A, TIM3, and TIGIT have been studied (52, 128-130). NK cells can express FcyRIIIA/CD16a and/or FcrRIIC, which bind to the Fc portion of human immunoglobulins. Once antibodies bind to targets, NK cells are able to recognize the Fc portion and lyse target cells through antibody-dependent cell-mediated cytotoxicity (ADCC) (131). So, the combination of immune checkpoint inhibitors and NK cell-based therapy may be potential. Although, Nivolumab failed to improve overall survival of patients with recurrent glioblastoma. Studies have found that cancer type 1 or 2 susceptibility gene (BRCA1/2) alteration was associated with higher tumor mutation burden(TMB) and may serve as a novel indicator associated with better treatment outcomes of immune checkpoint inhibitors (132). The function of BRCA1/2 and other DNA mismatch repair gene alteration are worth being investigated in glioma. Most GBM cells express high levels of MHC class I molecules (112). Thus, blockade of such KIRs with antibodies may enhance NK-cell mediated killing. 
NK cells and T cells originate from a common ancestor and share many similarities. Both interact with MHC class I molecules, contributing to innate and adaptive immunity. They have similar cell-surface phenotypes and cellular functions, such as cytotoxicity, secretion of cytokines, and interaction with DCs (133). NK cells also play a role in regulating $T$ cell response. For example, NK cells can produce IFN-gamma, which promotes CD4+ T cell differentiation into TH1 helper cells (134). The latter contributes to an enhanced CD8+ T cell response (135). NK cells produce IFN-gamma, leading to DC maturation and IL12 secretion, which is sufficient for CD8+ T cell activation independent of CD4+ T cell (136). As an important constituent of the innate immunity response, NK cells can kill target cells and release antigen for cross-presentation and activation of T cells (137). NK cells can also negatively regulate a $\mathrm{T}$ cell response as described above or in the setting of acute viral infections $(138,139)$. A combination of NK cells and T cells comprise an ideal potential therapy for tumor treatment. A study has reported that CAR-NK cells can eliminate myeloid-derived suppressor cells and rescue impaired CAR-T cell activity against solid tumors (140). Moreover, CAR-NK cells can improve the infiltration and functions of subsequently infused CAR-T cells by secreting proinflammatory cytokines and chemokines (140). Cózar et al. found marked NK-cell infiltration in solid tumors were also infiltrated with T cells (117).Anti-IL13R $\alpha$, anti-HER2, and anti-EGFRvIII CAR-T have been tested in glioma (141-143). Utilizing the safety of CAR-NK cells and the high efficacy of CAR-T cells is worth exploring in gliomas.

Oncolytic virus (OV) OVs have a double oncolytic action by both directly attacking the cancer cells and inspiring a tumor specific immune response. OVs can be engineered to repress antibodies targeting tumor antigen and/or secret cytokines activating immune response. Xilin Chen et al. observed that the combination of EGFR-CAR NK-92 cells with oHSV-1

\section{REFERENCES}

1. Janjua TI, Rewatkar P, Ahmed-Cox A, Saeed I, Mansfeld FM, Kulshreshtha $\mathrm{R}$, et al. Frontiers in the Treatment of Glioblastoma: Past, Present and Emerging. Adv Drug Delivery Rev (2021) 171:108-38. doi: 10.1016/ j.addr.2021.01.012

2. Hamisch CA, Minartz J, Blau T, Hafkemeyer V, Rueß D, Hellerbach A, et al. Frame-Based Stereotactic Biopsy of Deep-Seated and Midline Structures in 511 Procedures: Feasibility, Risk Profile, and Diagnostic Yield. Acta Neurochir (Wien) (2019) 161(10):2065-71. doi: 10.1007/s00701-01904020-1

3. Buckner JC, Shaw EG, Pugh SL, Chakravarti A, Gilbert MR, Barger GR, et al. Radiation Plus Procarbazine, CCNU, and Vincristine in Low-Grade Glioma. N Engl J Med (2016) 374(14):1344-55. doi: 10.1056/NEJMoa1500925

4. Cloughesy TF, Mochizuki AY, Orpilla JR, Hugo W, Lee AH, Davidson TB, et al. Neoadjuvant Anti-PD-1 Immunotherapy Promotes a Survival Benefit With Intratumoral and Systemic Immune Responses in Recurrent Glioblastoma. Nat Med (2019) 25(3):477-86. doi: 10.1038/s41591-018-0337-7

5. June CH, O'Connor RS, Kawalekar OU, Ghassemi S, Milone MC. CAR T Cell Immunotherapy for Human Cancer. Science (2018) 359(6382):1361-5. doi: 10.1126/science.aar6711

6. Kochenderfer JN, Dudley ME, Kassim SH, Somerville RP, Carpenter RO, Stetler-Stevenson M, et al. Chemotherapy-Refractory Diffuse Large B-Cell Lymphoma and Indolent B-Cell Malignancies can be Effectively Treated resulted in more efficient killing of MDA-MB-231 tumor cells and significantly longer survival of tumor-bearing mice (144). Rui Ma et al. (145) generated a therapy that combined off-theshelf EGFR-CAR NK cells and an Oncolytic virus OV called OVIL15C. OV-IL15C-infected GBM cells can secrete soluble IL15/ IL15R $\alpha$ complex. GBM-bearing mice models exhibited that the therapy synergistically suppressed tumor growth. These potential therapies are anticipated to be further investigated in clinical trials. Combination therapies are based on the knowledge of NK cell biology. An evolving understanding of gliomas can inspire treatment strategies targeting the basic elements of these malignant cells and their microenvironments. We believe NK cell-based immunotherapy will have a better performance in treating glioma in the future.

\section{AUTHOR CONTRIBUTIONS}

$\mathrm{CP}$ conceived the article. $\mathrm{YZ}$ compiled the review and prepared the draft of the manuscript. GL, TJ, and WZ reviewed and edited the manuscript. All authors contributed to the article and approved the submitted version.

\section{FUNDING}

This work was supported by grants from National Natural Science Foundation of China (No.82072768), Construction Project of Multi Omics Platform for Major Brain Diseases (PXM2019_026280_000002), Sino German Cooperation and Exchange Project (Mobility Programme, M-0020), Research Fund for Clinical and Translational Medicine of Chinese Academy of Medical Sciences (2020-I2M-C\&T-A-024).
With Autologous T Cells Expressing an Anti-CD19 Chimeric Antigen Receptor. J Clin Oncol (2015) 33(6):540-9. doi: 10.1200/jco.2014.56.2025

7. Park JH, Rivière I, Gonen M, Wang X, Sénéchal B, Curran KJ, et al. LongTerm Follow-Up of CD19 CAR Therapy in Acute Lymphoblastic Leukemia. N Engl J Med (2018) 378(5):449-59. doi: 10.1056/NEJMoa1709919

8. Singh AK, McGuirk JP. CAR T Cells: Continuation in a Revolution of Immunotherapy. Lancet Oncol (2020) 21(3):e168-e78. doi: 10.1016/s14702045(19)30823-x

9. Vivier E, Tomasello E, Baratin M, Walzer T, Ugolini S. Functions of Natural Killer Cells. Nat Immunol (2008) 9(5):503-10. doi: 10.1038/ni1582

10. Zhang Y, Wallace DL, de Lara CM, Ghattas H, Asquith B, Worth A, et al. In Vivo Kinetics of Human Natural Killer Cells: The Effects of Ageing and Acute and Chronic Viral Infection. Immunology (2007) 121(2):258-65. doi: 10.1111/j.1365-2567.2007.02573.x

11. Keating SE, Zaiatz-Bittencourt V, Loftus RM, Keane C, Brennan K, Finlay DK, et al. Metabolic Reprogramming Supports IFN- $\gamma$ Production by CD56bright NK Cells. J Immunol (2016) 196(6):2552-60. doi: 10.4049/ jimmunol.1501783

12. Stringaris K, Sekine T, Khoder A, Alsuliman A, Razzaghi B, Sargeant R, et al. Leukemia-Induced Phenotypic and Functional Defects in Natural Killer Cells Predict Failure to Achieve Remission in Acute Myeloid Leukemia. Haematologica (2014) 99(5):836-47. doi: 10.3324/haematol.2013.087536

13. Rubnitz JE, Inaba H, Ribeiro RC, Pounds S, Rooney B, Bell T, et al. NKAML: A Pilot Study to Determine the Safety and Feasibility of Haploidentical 
Natural Killer Cell Transplantation in Childhood Acute Myeloid Leukemia. J Clin Oncol (2010) 28(6):955-9. doi: 10.1200/jco.2009.24.4590

14. Miller JS, Soignier Y, Panoskaltsis-Mortari A, McNearney SA, Yun GH, Fautsch SK, et al. Successful Adoptive Transfer and In Vivo Expansion of Human Haploidentical NK Cells in Patients With Cancer. Blood (2005) 105 (8):3051-7. doi: 10.1182/blood-2004-07-2974

15. Morvan MG, Lanier LL. NK Cells and Cancer: You can Teach Innate Cells New Tricks. Nat Rev Cancer (2016) 16(1):7-19. doi: 10.1038/nrc.2015.5

16. Liu E, Marin D, Banerjee P, Macapinlac HA, Thompson P, Basar R, et al. Use of CAR-Transduced Natural Killer Cells in CD19-Positive Lymphoid Tumors. N Engl J Med (2020) 382(6):545-53. doi: 10.1056/NEJMoa1910607

17. Colonna M, Samaridis J. Cloning of Immunoglobulin-Superfamily Members Associated With HLA-C and HLA-B Recognition by Human Natural Killer Cells. Science (1995) 268(5209):405-8. doi: 10.1126/science.7716543

18. Ruggeri L, Mancusi A, Capanni M, Urbani E, Carotti A, Aloisi T, et al. Donor Natural Killer Cell Allorecognition of Missing Self in Haploidentical Hematopoietic Transplantation for Acute Myeloid Leukemia: Challenging Its Predictive Value. Blood (2007) 110(1):433-40. doi: 10.1182/blood-200607-038687

19. Storkus WJ, Howell DN, Salter RD, Dawson JR, Cresswell P. NK Susceptibility Varies Inversely With Target Cell Class I HLA Antigen Expression. J Immunol (1987) 138(6):1657-9.

20. Moretta A, Vitale M, Bottino C, Orengo AM, Morelli L, Augugliaro R, et al. P58 Molecules as Putative Receptors for Major Histocompatibility Complex (MHC) Class I Molecules in Human Natural Killer (NK) Cells. Anti-P58 Antibodies Reconstitute Lysis of MHC Class I-Protected Cells in NK Clones Displaying Different Specificities. J Exp Med (1993) 178(2):597-604. doi: $10.1084 /$ jem.178.2.597

21. Pende D, Falco M, Vitale M, Cantoni C, Vitale C, Munari E, et al. Killer IgLike Receptors (KIRs): Their Role in NK Cell Modulation and Developments Leading to Their Clinical Exploitation. Front Immunol (2019) 101179:1179. doi: 10.3389/fimmu.2019.01179

22. Uhrberg M, Valiante NM, Shum BP, Shilling HG, Lienert-Weidenbach K, Corliss B, et al. Human Diversity in Killer Cell Inhibitory Receptor Genes. Immunity (1997) 7(6):753-63. doi: 10.1016/s1074-7613(00)80394-5

23. Colonna M, Brooks EG, Falco M, Ferrara GB, Strominger JL. Generation of Allospecific Natural Killer Cells by Stimulation Across a Polymorphism of HLA-C. Science (1993) 260(5111):1121-4. doi: 10.1126/science.8493555

24. López-Botet M, Pérez-Villar JJ, Carretero M, Rodríguez A, Melero I, Bellón T, et al. Structure and Function of the CD94 C-Type Lectin Receptor Complex Involved in Recognition of HLA Class I Molecules. Immunol Rev (1997) 155:165-74. doi: 10.1111/j.1600-065x.1997.tb00949.x

25. Brooks AG, Posch PE, Scorzelli CJ, Borrego F, Coligan JE. NKG2A Complexed With CD94 Defines a Novel Inhibitory Natural Killer Cell Receptor. J Exp Med (1997) 185(4):795-800. doi: 10.1084/jem.185.4.795

26. Carretero M, Cantoni C, Bellón T, Bottino C, Biassoni R, Rodríguez A, et al. The CD94 and NKG2-A C-Type Lectins Covalently Assemble to Form a Natural Killer Cell Inhibitory Receptor for HLA Class I Molecules. Eur J Immunol (1997) 27(2):563-7. doi: 10.1002/eji.1830270230

27. Kärre K, Ljunggren HG, Piontek G, Kiessling R. Selective Rejection of H-2Deficient Lymphoma Variants Suggests Alternative Immune Defence Strategy. Nature (1986) 319(6055):675-8. doi: 10.1038/319675a0

28. Farag SS, Fehniger TA, Ruggeri L, Velardi A, Caligiuri MA. Natural Killer Cell Receptors: New Biology and Insights Into the Graft-Versus-Leukemia Effect. Blood (2002) 100(6):1935-47. doi: 10.1182/blood-2002-02-0350

29. Kärre K. NK Cells, MHC Class I Molecules and the Missing Self. Scand J Immunol (2002) 55(3):221-8. doi: 10.1046/j.1365-3083.2002.01053.x

30. Ruggeri L, Capanni M, Casucci M, Volpi I, Tosti A, Perruccio K, et al. Role of Natural Killer Cell Alloreactivity in HLA-Mismatched Hematopoietic Stem Cell Transplantation. Blood (1999) 94(1):333-9. doi: 10.1182/blood.V94. 1.333.413a31_333_339

31. Yabe T, McSherry C, Bach FH, Fisch P, Schall RP, Sondel PM, et al. A Multigene Family on Human Chromosome 12 Encodes Natural Killer-Cell Lectins. Immunogenetics (1993) 37(6):455-60. doi: 10.1007/bf00222470

32. Gumperz JE, Valiante NM, Parham P, Lanier LL, Tyan D. Heterogeneous Phenotypes of Expression of the NKB1 Natural Killer Cell Class I Receptor Among Individuals of Different Human Histocompatibility Leukocyte Antigens Types Appear Genetically Regulated, But Not Linked to Major
Histocompatibililty Complex Haplotype. J Exp Med (1996) 183(4):1817-27. doi: $10.1084 /$ jem.183.4.1817

33. Vilches C, Parham P. KIR: Diverse, Rapidly Evolving Receptors of Innate and Adaptive Immunity. Annu Rev Immunol (2002) 20:217-51. doi: 10.1146/annurev.immunol.20.092501.134942

34. Hsu KC, Keever-Taylor CA, Wilton A, Pinto C, Heller G, Arkun K, et al. Improved Outcome in HLA-Identical Sibling Hematopoietic Stem-Cell Transplantation for Acute Myelogenous Leukemia Predicted by KIR and HLA Genotypes. Blood (2005) 105(12):4878-84. doi: 10.1182/blood-2004$12-4825$

35. Leung W, Iyengar R, Triplett B, Turner V, Behm FG, Holladay MS, et al. Comparison of Killer Ig-Like Receptor Genotyping and Phenotyping for Selection of Allogeneic Blood Stem Cell Donors. J Immunol (2005) 174 (10):6540-5. doi: 10.4049/jimmunol.174.10.6540

36. Leung W, Iyengar R, Turner V, Lang P, Bader P, Conn P, et al. Determinants of Antileukemia Effects of Allogeneic NK Cells. J Immunol (2004) 172 (1):644-50. doi: 10.4049/jimmunol.172.1.644

37. Hsu KC, Gooley T, Malkki M, Pinto-Agnello C, Dupont B, Bignon JD, et al. KIR Ligands and Prediction of Relapse After Unrelated Donor Hematopoietic Cell Transplantation for Hematologic Malignancy. Biol Blood Marrow Transplant (2006) 12(8):828-36. doi: 10.1016/ j.bbmt.2006.04.008

38. Verheyden S, Schots R, Duquet W, Demanet C. A Defined Donor Activating Natural Killer Cell Receptor Genotype Protects Against Leukemic Relapse After Related HLA-Identical Hematopoietic Stem Cell Transplantation. Leukemia (2005) 19(8):1446-51. doi: 10.1038/sj.leu.2403839

39. Sconocchia G, Lau M, Provenzano M, Rezvani K, Wongsena W, Fujiwara H, et al. The Antileukemia Effect of HLA-Matched NK and NK-T Cells in Chronic Myelogenous Leukemia Involves NKG2D-Target-Cell Interactions. Blood (2005) 106(10):3666-72. doi: 10.1182/blood-2005-02-0479

40. Verheyden S, Demanet C. NK Cell Receptors and Their Ligands in Leukemia. Leukemia (2008) 22(2):249-57. doi: 10.1038/sj.leu.2405040

41. Shimasaki N, Jain A, Campana D. NK Cells for Cancer Immunotherapy. Nat Rev Drug Discovery (2020) 19(3):200-18. doi: 10.1038/s41573-019-0052-1

42. Weiden PL, Flournoy N, Thomas ED, Prentice R, Fefer A, Buckner CD, et al. Antileukemic Effect of Graft-Versus-Host Disease in Human Recipients of Allogeneic-Marrow Grafts. N Engl J Med (1979) 300(19):1068-73. doi: 10.1056/nejm197905103001902

43. Horowitz MM, Gale RP, Sondel PM, Goldman JM, Kersey J, Kolb HJ, et al. Graft-Versus-Leukemia Reactions After Bone Marrow Transplantation. Blood (1990) 75(3):555-62. doi: 10.1182/blood.V75.3.555.555

44. Ferrara JL, Levine JE, Reddy P, Holler E. Graft-Versus-Host Disease. Lancet (2009) 373(9674):1550-61. doi: 10.1016/s0140-6736(09)60237-3

45. Giebel S, Locatelli F, Lamparelli T, Velardi A, Davies S, Frumento G, et al. Survival Advantage With KIR Ligand Incompatibility in Hematopoietic Stem Cell Transplantation From Unrelated Donors. Blood (2003) 102 (3):814-9. doi: 10.1182/blood-2003-01-0091

46. Ruggeri L, Capanni M, Urbani E, Perruccio K, Shlomchik WD, Tosti A, et al. Effectiveness of Donor Natural Killer Cell Alloreactivity in Mismatched Hematopoietic Transplants. Science (2002) 295(5562):2097-100. doi: $10.1126 /$ science. 1068440

47. Cerboni C, Zingoni A, Cippitelli M, Piccoli M, Frati L, Santoni A. AntigenActivated Human T Lymphocytes Express Cell-Surface NKG2D Ligands via an ATM/ATR-Dependent Mechanism and Become Susceptible to Autologous NK- Cell Lysis. Blood (2007) 110(2):606-15. doi: 10.1182/ blood-2006-10-052720

48. Miller JS, Cooley S, Parham P, Farag SS, Verneris MR, McQueen KL, et al. Missing KIR Ligands are Associated With Less Relapse and Increased GraftVersus-Host Disease (GVHD) Following Unrelated Donor Allogeneic HCT. Blood (2007) 109(11):5058-61. doi: 10.1182/blood-2007-01-065383

49. Barnes DW, Corp MJ, Loutit JF, Neal FE. Treatment of Murine Leukaemia With X Rays and Homologous Bone Marrow; Preliminary Communication. Br Med J (1956) 2(4993):626-7. doi: 10.1136/bmj.2.4993.626

50. Bachar-Lustig E, Rachamim N, Li HW, Lan F, Reisner Y. Megadose of T Cell-Depleted Bone Marrow Overcomes MHC Barriers in Sublethally Irradiated Mice. Nat Med (1995) 1(12):1268-73. doi: 10.1038/nm1295-1268

51. Valiante NM, Uhrberg M, Shilling HG, Lienert-Weidenbach K, Arnett KL, D'Andrea A, et al. Functionally and Structurally Distinct NK Cell Receptor 
Repertoires in the Peripheral Blood of Two Human Donors. Immunity (1997) 7(6):739-51. doi: 10.1016/s1074-7613(00)80393-3

52. André P, Denis C, Soulas C, Bourbon-Caillet C, Lopez J, Arnoux T, et al. Anti-NKG2A mAb Is a Checkpoint Inhibitor That Promotes Anti-Tumor Immunity by Unleashing Both T and NK Cells. Cell (2018) 175(7):173143.e13. doi: 10.1016/j.cell.2018.10.014

53. Braud V, Jones EY, McMichael A. The Human Major Histocompatibility Complex Class Ib Molecule HLA-E Binds Signal Sequence-Derived Peptides With Primary Anchor Residues at Positions 2 and 9. Eur J Immunol (1997) 27(5):1164-9. doi: 10.1002/eji.1830270517

54. Braud VM, Allan DS, Wilson D, McMichael AJ. TAP- and TapasinDependent HLA-E Surface Expression Correlates With the Binding of an MHC Class I Leader Peptide. Curr Biol (1998) 8(1):1-10. doi: 10.1016/ s0960-9822(98)70014-4

55. Bauer S, Groh V, Wu J, Steinle A, Phillips JH, Lanier LL, et al. Activation of NK Cells and T Cells by NKG2D, a Receptor for Stress-Inducible MICA. Science (1999) 285(5428):727-9. doi: 10.1126/science.285.5428.727

56. Cosman D, Müllberg J, Sutherland CL, Chin W, Armitage R, Fanslow W, et al. ULBPs, Novel MHC Class I-Related Molecules, Bind to CMV Glycoprotein UL16 and Stimulate NK Cytotoxicity Through the NKG2D Receptor. Immunity (2001) 14(2):123-33. doi: 10.1016/s1074-7613(01) 00095-4

57. Fajgenbaum DC, June CH. Cytokine Storm. N Engl J Med (2020) 383 (23):2255-73. doi: 10.1056/NEJMra2026131

58. Klingemann H. Are Natural Killer Cells Superior CAR Drivers? Oncoimmunology (2014) 3:e28147. doi: 10.4161/onci.28147

59. Tang X, Yang L, Li Z, Nalin AP, Dai H, Xu T, et al. First-In-Man Clinical Trial of CAR NK-92 Cells: Safety Test of CD33-CAR NK-92 Cells in Patients With Relapsed and Refractory Acute Myeloid Leukemia. Am J Cancer Res (2018) 8(6):1083-9.

60. Parkhurst MR, Riley JP, Dudley ME, Rosenberg SA. Adoptive Transfer of Autologous Natural Killer Cells Leads to High Levels of Circulating Natural Killer Cells But Does Not Mediate Tumor Regression. Clin Cancer Res (2011) 17(19):6287-97. doi: 10.1158/1078-0432.Ccr-11-1347

61. Maki G, Klingemann HG, Martinson JA, Tam YK. Factors Regulating the Cytotoxic Activity of the Human Natural Killer Cell Line, NK-92. J Hematother Stem Cell Res (2001) 10(3):369-83. doi: 10.1089/ 152581601750288975

62. Schönfeld K, Sahm C, Zhang C, Naundorf S, Brendel C, Odendahl M, et al. Selective Inhibition of Tumor Growth by Clonal NK Cells Expressing an ErbB2/HER2-Specific Chimeric Antigen Receptor. Mol Ther (2015) 23 (2):330-8. doi: 10.1038/mt.2014.219

63. Vela M, Corral D, Carrasco P, Fernández L, Valentín J, González B, et al. Haploidentical IL-15/41BBL Activated and Expanded Natural Killer Cell Infusion Therapy After Salvage Chemotherapy in Children With Relapsed and Refractory Leukemia. Cancer Lett (2018) 422:107-17. doi: 10.1016/ j.canlet.2018.02.033

64. Ciurea SO, Schafer JR, Bassett R, Denman CJ, Cao K, Willis D, et al. Phase 1 Clinical Trial Using Mbil21 Ex Vivo-Expanded Donor-Derived NK Cells After Haploidentical Transplantation. Blood (2017) 130(16):1857-68. doi: 10.1182/blood-2017-05-785659

65. Huntington ND, Puthalakath H, Gunn P, Naik E, Michalak EM, Smyth MJ, et al. Interleukin 15-Mediated Survival of Natural Killer Cells Is Determined by Interactions Among Bim, Noxa and Mcl-1. Nat Immunol (2007) 8 (8):856-63. doi: 10.1038/ni1487

66. Guo Y, Luan L, Patil NK, Sherwood ER. Immunobiology of the IL-15/IL$15 \mathrm{r} \alpha$ Complex as an Antitumor and Antiviral Agent. Cytokine Growth Factor Rev (2017) 38:10-21. doi: 10.1016/j.cytogfr.2017.08.002

67. Robertson MJ, Cameron C, Lazo S, Cochran KJ, Voss SD, Ritz J. Costimulation of Human Natural Killer Cell Proliferation: Role of Accessory Cytokines and Cell Contact-Dependent Signals. Nat Immun (1996) 15(5):213-26.

68. Sakamoto N, Ishikawa $\mathrm{T}$, Kokura $\mathrm{S}$, Okayama $\mathrm{T}$, Oka $\mathrm{K}$, Ideno $\mathrm{M}$, et al. Phase I Clinical Trial of Autologous NK Cell Therapy Using Novel Expansion Method in Patients With Advanced Digestive Cancer. J Transl Med (2015) 13:277. doi: 10.1186/s12967-015-0632-8

69. Ishikawa T, Okayama T, Sakamoto N, Ideno M, Oka K, Enoki T, et al. Phase I Clinical Trial of Adoptive Transfer of Expanded Natural Killer Cells in
Combination With IgG1 Antibody in Patients With Gastric or Colorectal Cancer. Int J Cancer (2018) 142(12):2599-609. doi: 10.1002/ijc.31285

70. Ruoslahti E. Fibronectin and its Receptors. Annu Rev Biochem (1988) 57:375-413. doi: 10.1146/annurev.bi.57.070188.002111

71. Rabinovich BA, Li J, Shannon J, Hurren R, Chalupny J, Cosman D, et al. Activated, But Not Resting, T Cells can be Recognized and Killed by Syngeneic NK Cells. J Immunol (2003) 170(7):3572-6. doi: 10.4049/ jimmunol.170.7.3572

72. Lee HR, Son CH, Koh EK, Bae JH, Kang CD, Yang K, et al. Expansion of Cytotoxic Natural Killer Cells Using Irradiated Autologous Peripheral Blood Mononuclear Cells and Anti-CD16 Antibody. Sci Rep (2017) 7(1):11075. doi: 10.1038/s41598-017-09259-1

73. Miller JS, Oelkers S, Verfaillie C, McGlave P. Role of Monocytes in the Expansion of Human Activated Natural Killer Cells. Blood (1992) 80 (9):2221-9. doi: 10.1182/blood.V80.9.2221.2221

74. Li L, Li W, Wang C, Yan X, Wang Y, Niu C, et al. Adoptive Transfer of Natural Killer Cells in Combination With Chemotherapy Improves Outcomes of Patients With Locally Advanced Colon Carcinoma. Cytotherapy (2018) 20(1):134-48. doi: 10.1016/j.jcyt.2017.09.009

75. Lehrnbecher T, Foster CB, Zhu S, Leitman SF, Goldin LR, Huppi K, et al. Variant Genotypes of the Low-Affinity Fcgamma Receptors in Two Control Populations and a Review of Low-Affinity Fcgamma Receptor Polymorphisms in Control and Disease Populations. Blood (1999) 94 (12):4220-32. doi: 10.1182/blood.V94.12.4220.424k08_4220_4232

76. Freud AG, Mundy-Bosse BL, Yu J, Caligiuri MA. The Broad Spectrum of Human Natural Killer Cell Diversity. Immunity (2017) 47(5):820-33. doi: 10.1016/j.immuni.2017.10.008

77. Grimm EA, Mazumder A, Zhang HZ, Rosenberg SA. Lymphokine-Activated Killer Cell Phenomenon. Lysis of Natural Killer-Resistant Fresh Solid Tumor Cells by Interleukin 2-Activated Autologous Human Peripheral Blood Lymphocytes. J Exp Med (1982) 155(6):1823-41. doi: 10.1084/jem.155.6. 1823

78. Rosenberg SA, Spiess P, Lafreniere R. A New Approach to the Adoptive Immunotherapy of Cancer With Tumor-Infiltrating Lymphocytes. Science (1986) 233(4770):1318-21. doi: 10.1126/science.3489291

79. Restifo NP, Dudley ME, Rosenberg SA. Adoptive Immunotherapy for Cancer: Harnessing the T Cell Response. Nat Rev Immunol (2012) 12 (4):269-81. doi: 10.1038/nri3191

80. Zacharakis $\mathrm{N}$, Chinnasamy H, Black $\mathrm{M}, \mathrm{Xu} \mathrm{H}, \mathrm{Lu} \mathrm{YC}$, Zheng Z, et al. Immune Recognition of Somatic Mutations Leading to Complete Durable Regression in Metastatic Breast Cancer. Nat Med (2018) 24(6):724-30. doi: 10.1038/s41591-018-0040-8

81. Morgan RA, Dudley ME, Wunderlich JR, Hughes MS, Yang JC, Sherry RM, et al. Cancer Regression in Patients After Transfer of Genetically Engineered Lymphocytes. Science (2006) 314(5796):126-9. doi: 10.1126/science.1129003

82. Zhai Y, Li G, Jiang T, Zhang W. CAR-Armed Cell Therapy for Gliomas. Am J Cancer Res (2019) 9(12):2554-66.

83. Leen AM, Sukumaran S, Watanabe N, Mohammed S, Keirnan J, Yanagisawa $\mathrm{R}$, et al. Reversal of Tumor Immune Inhibition Using a Chimeric Cytokine Receptor. Mol Ther (2014) 22(6):1211-20. doi: 10.1038/mt.2014.47

84. Wang Y, Jiang H, Luo H, Sun Y, Shi B, Sun R, et al. An IL-4/21 Inverted Cytokine Receptor Improving CAR-T Cell Potency in Immunosuppressive Solid-Tumor Microenvironment. Front Immunol (2019) 10:1691. doi: $10.3389 /$ fimmu.2019.01691

85. Han X, Wang Y, Wei J, Han W. Multi-Antigen-Targeted Chimeric Antigen Receptor T Cells for Cancer Therapy. J Hematol Oncol (2019) 12(1):128. doi: 10.1186/s13045-019-0813-7

86. Xie G, Dong H, Liang Y, Ham JD, Rizwan R, Chen J. CAR-NK Cells: A Promising Cellular Immunotherapy for Cancer. EBioMedicine (2020) 59:102975. doi: 10.1016/j.ebiom.2020.102975

87. Klöß S, Oberschmidt O, Morgan M, Dahlke J, Arseniev L, Huppert V, et al. Optimization of Human NK Cell Manufacturing: Fully Automated Separation, Improved Ex Vivo Expansion Using IL-21 With Autologous Feeder Cells, and Generation of Anti-CD123-CAR-Expressing Effector Cells. Hum Gene Ther (2017) 28(10):897-913. doi: 10.1089/hum.2017.157

88. Tseng HC, Xiong W, Badeti S, Yang Y, Ma M, Liu T, et al. Efficacy of AntiCD147 Chimeric Antigen Receptors Targeting Hepatocellular Carcinoma. Nat Commun (2020) 11(1):4810. doi: 10.1038/s41467-020-18444-2 
89. Altvater B, Landmeier S, Pscherer S, Temme J, Schweer K, Kailayangiri S, et al. $2 \mathrm{~b} 4$ (CD244) Signaling by Recombinant Antigen-Specific Chimeric Receptors Costimulates Natural Killer Cell Activation to Leukemia and Neuroblastoma Cells. Clin Cancer Res (2009) 15(15):4857-66. doi: 10.1158/ 1078-0432.Ccr-08-2810

90. Müller N, Michen S, Tietze S, Töpfer K, Schulte A, Lamszus K, et al. Engineering NK Cells Modified With an EGFRvIII-Specific Chimeric Antigen Receptor to Overexpress CXCR4 Improves Immunotherapy of CXCL12/SDF-1 $\alpha$-Secreting Glioblastoma. J Immunother (2015) 38(5):197210. doi: $10.1097 / \mathrm{cji} .0000000000000082$

91. Li Y, Hermanson DL, Moriarity BS, Kaufman DS. Human iPSC-Derived Natural Killer Cells Engineered With Chimeric Antigen Receptors Enhance Anti-Tumor Activity. Cell Stem Cell (2018) 23(2):181-92.e5. doi: 10.1016/ j.stem.2018.06.002

92. Billadeau DD, Upshaw JL, Schoon RA, Dick CJ, Leibson PJ. NKG2D-DAP10 Triggers Human NK Cell-Mediated Killing via a Syk-Independent Regulatory Pathway. Nat Immunol (2003) 4(6):557-64. doi: 10.1038/ni929

93. Bryceson YT, March ME, Ljunggren HG, Long EO. Activation, Coactivation, and Costimulation of Resting Human Natural Killer Cells. Immunol Rev (2006) 214:73-91. doi: 10.1111/j.1600-065X.2006.00457.x

94. Eissmann P, Beauchamp L, Wooters J, Tilton JC, Long EO, Watzl C. Molecular Basis for Positive and Negative Signaling by the Natural Killer Cell Receptor 2B4 (CD244). Blood (2005) 105(12):4722-9. doi: 10.1182/ blood-2004-09-3796

95. Chakravarthy A, Furness A, Joshi K, Ghorani E, Ford K, Ward MJ, et al. PanCancer Deconvolution of Tumour Composition Using DNA Methylation. Nat Commun (2018) 9(1):3220. doi: 10.1038/s41467-018-05570-1

96. Mahaley MSJr., Gentry RE, Bigner DD. Immunobiology of Primary Intracranial Tumors. J Neurosurg (1977) 47(1):35-43. doi: 10.3171/ jns.1977.47.1.0035

97. Elliott LH, Brooks WH, Roszman TL. Activation of Immunoregulatory Lymphocytes Obtained From Patients With Malignant Gliomas. J Neurosurg (1987) 67(2):231-6. doi: 10.3171/jns.1987.67.2.0231

98. McVicar DW, Davis DF, Merchant RE. In Vitro Analysis of the Proliferative Potential of T Cells From Patients With Brain Tumor: Glioma-Associated Immunosuppression Unrelated to Intrinsic Cellular Defect. J Neurosurg (1992) 76(2):251-60. doi: 10.3171/jns.1992.76.2.0251

99. Ashkenazi E, Deutsch M, Tirosh R, Weinreb A, Tsukerman A, Brodie C. A Selective Impairment of the IL-2 System in Lymphocytes of Patients With Glioblastomas: Increased Level of Soluble IL-2R and Reduced Protein Tyrosine Phosphorylation. Neuroimmunomodulation (1997) 4(1):49-56. doi: $10.1159 / 000097315$

100. Morford LA, Elliott LH, Carlson SL, Brooks WH, Roszman TL. T Cell Receptor-Mediated Signaling is Defective in T Cells Obtained From Patients With Primary Intracranial Tumors. J Immunol (1997) 159(9):4415-25.

101. Raychaudhuri B, Rayman P, Ireland J, Ko J, Rini B, Borden EC, et al. Myeloid-Derived Suppressor Cell Accumulation and Function in Patients With Newly Diagnosed Glioblastoma. Neuro Oncol (2011) 13(6):591-9. doi: 10.1093/neuonc/nor042

102. Rodrigues JC, Gonzalez GC, Zhang L, Ibrahim G, Kelly JJ, Gustafson MP, et al. Normal Human Monocytes Exposed to Glioma Cells Acquire MyeloidDerived Suppressor Cell-Like Properties. Neuro Oncol (2010) 12(4):351-65. doi: 10.1093/neuonc/nop023

103. Sinha P, Clements VK, Bunt SK, Albelda SM, Ostrand-Rosenberg S. CrossTalk Between Myeloid-Derived Suppressor Cells and Macrophages Subverts Tumor Immunity Toward a Type 2 Response. J Immunol (2007) 179(2):97783. doi: 10.4049/jimmunol.179.2.977

104. Friese MA, Wischhusen J, Wick W, Weiler M, Eisele G, Steinle A, et al. RNA Interference Targeting Transforming Growth Factor-Beta Enhances NKG2D-Mediated Antiglioma Immune Response, Inhibits Glioma Cell Migration and Invasiveness, and Abrogates Tumorigenicity In Vivo. Cancer Res (2004) 64(20):7596-603. doi: 10.1158/0008-5472.Can-04-1627

105. Castriconi R, Cantoni C, Della Chiesa M, Vitale M, Marcenaro E, Conte R, et al. Transforming Growth Factor Beta 1 Inhibits Expression of NKp30 and NKG2D Receptors: Consequences for the NK-Mediated Killing of Dendritic Cells. Proc Natl Acad Sci USA (2003) 100(7):4120-5. doi: 10.1073/ pnas. 0730640100
106. Viel S, Marçais A, Guimaraes FS, Loftus R, Rabilloud J, Grau M, et al. TGF- $\beta$ Inhibits the Activation and Functions of NK Cells by Repressing the mTOR Pathway. Sci Signal (2016) 9(415):ra19. doi: 10.1126/scisignal.aad1884

107. Close HJ, Stead LF, Nsengimana J, Reilly KA, Droop A, Wurdak H, et al. Expression Profiling of Single Cells and Patient Cohorts Identifies Multiple Immunosuppressive Pathways and an Altered NK Cell Phenotype in Glioblastoma. Clin Exp Immunol (2020) 200(1):33-44. doi: 10.1111/ cei.13403

108. Wei J, Barr J, Kong LY, Wang Y, Wu A, Sharma AK, et al. Glioblastoma Cancer-Initiating Cells Inhibit T-Cell Proliferation and Effector Responses by the Signal Transducers and Activators of Transcription 3 Pathway. Mol Cancer Ther (2010) 9(1):67-78. doi: 10.1158/1535-7163.Mct-09-0734

109. Kinjyo I, Inoue H, Hamano S, Fukuyama S, Yoshimura T, Koga K, et al. Loss of SOCS3 in T Helper Cells Resulted in Reduced Immune Responses and Hyperproduction of Interleukin 10 and Transforming Growth Factor-Beta 1. J Exp Med (2006) 203(4):1021-31. doi: 10.1084/jem.20052333

110. Laudati E, Currò D, Navarra P, Lisi L. Blockade of CCR5 Receptor Prevents M2 Microglia Phenotype in a Microglia-Glioma Paradigm. Neurochem Int (2017) 108:100-8. doi: 10.1016/j.neuint.2017.03.002

111. Held-Feindt J, Hattermann K, Müerköster SS, Wedderkopp H, KnerlichLukoschus F, Ungefroren $\mathrm{H}$, et al. CX3CR1 Promotes Recruitment of Human Glioma-Infiltrating Microglia/Macrophages (GIMs). Exp Cell Res (2010) 316(9):1553-66. doi: 10.1016/j.yexcr.2010.02.018

112. Golán I, Rodríguez de la Fuente L, Costoya JA. NK Cell-Based Glioblastoma Immunotherapy. Cancers (Basel) (2018) 10(12):522. doi: 10.3390/ cancers 10120522

113. O’Brien KL, Finlay DK. Immunometabolism and Natural Killer Cell Responses. Nat Rev Immunol (2019) 19(5):282-90. doi: 10.1038/s41577019-0139-2

114. Tassinari V, Cesarini V, Tomaselli S, Ianniello Z, Silvestris DA, Ginistrelli LC, et al. ADAR1 is a New Target of METTL3 and Plays a Pro-Oncogenic Role in Glioblastoma by an Editing-Independent Mechanism. Genome Biol (2021) 22(1):51. doi: 10.1186/s13059-021-02271-9

115. Chang YZ, Chai RC, Pang B, Chang X, An SY, Zhang KN, et al. METTL3 Enhances the Stability of MALAT1 With the Assistance of HuR via M6a Modification and Activates NF- $\mathrm{kb}$ to Promote the Malignant Progression of IDH-Wildtype Glioma. Cancer Lett (2021) 511:36-46. doi: 10.1016/ j.canlet.2021.04.020

116. Zhou Z, Zhang J, Xu C, Yang J, Zhang Y, Liu M, et al. An Integrated Model of N6-Methyladenosine Regulators to Predict Tumor Aggressiveness and Immune Evasion in Pancreatic Cancer. EBioMedicine (2021) 65:103271. doi: 10.1016/j.ebiom.2021.103271

117. Cózar B, Greppi M, Carpentier S, Narni-Mancinelli E, Chiossone L, Vivier E. Tumor-Infiltrating Natural Killer Cells. Cancer Discovery (2021) 11(1):3444. doi: 10.1158/2159-8290.Cd-20-0655

118. Genßler S, Burger MC, Zhang C, Oelsner S, Mildenberger I, Wagner M, et al. Dual Targeting of Glioblastoma With Chimeric Antigen Receptor-Engineered Natural Killer Cells Overcomes Heterogeneity of Target Antigen Expression and Enhances Antitumor Activity and Survival. Oncoimmunology (2016) 5(4): e1119354. doi: 10.1080/2162402x.2015.1119354

119. Murakami T, Nakazawa T, Natsume A, Nishimura F, Nakamura M, Matsuda $\mathrm{R}$, et al. Novel Human NK Cell Line Carrying CAR Targeting EGFRvIII Induces Antitumor Effects in Glioblastoma Cells. Anticancer Res (2018) 38 (9):5049-56. doi: 10.21873/anticanres.12824

120. Han J, Chu J, Keung Chan W, Zhang J, Wang Y, Cohen JB, et al. CAREngineered NK Cells Targeting Wild-Type EGFR and EGFRvIII Enhance Killing of Glioblastoma and Patient-Derived Glioblastoma Stem Cells. Sci Rep (2015) 5:11483. doi: 10.1038/srep11483

121. Alkins R, Burgess A, Kerbel R, Wels WS, Hynynen K. Early Treatment of HER2-Amplified Brain Tumors With Targeted NK-92 Cells and Focused Ultrasound Improves Survival. Neuro Oncol (2016) 18(7):974-81. doi: $10.1093 /$ neuonc/nov318

122. Zhang C, Burger MC, Jennewein L, Genßler S, Schönfeld K, Zeiner P, et al. ErbB2/HER2-Specific NK Cells for Targeted Therapy of Glioblastoma. J Natl Cancer Inst (2016) 108(5). doi: 10.1093/jnci/djv375

123. Burger MC, Zhang C, Harter PN, Romanski A, Strassheimer F, Senft C, et al. CAR-Engineered NK Cells for the Treatment of Glioblastoma: Turning 
Innate Effectors Into Precision Tools for Cancer Immunotherapy. Front Immunol (2019) 10:2683. doi: 10.3389/fimmu.2019.02683

124. Wu W, Zhou Q, Masubuchi T, Shi X, Li H, Xu X, et al. Multiple Signaling Roles of CD3€ and Its Application in CAR-T Cell Therapy. Cell (2020) 182 (4):855-71.e23. doi: 10.1016/j.cell.2020.07.018

125. Bryceson YT, March ME, Ljunggren HG, Long EO. Synergy Among Receptors on Resting NK Cells for the Activation of Natural Cytotoxicity and Cytokine Secretion. Blood (2006) 107(1):159-66. doi: 10.1182/blood2005-04-1351

126. Gauthier L, Morel A, Anceriz N, Rossi B, Blanchard-Alvarez A, Grondin G, et al. Multifunctional Natural Killer Cell Engagers Targeting NKp46 Trigger Protective Tumor Immunity. Cell (2019) 177(7):1701-13.e16. doi: 10.1016/ j.cell.2019.04.041

127. Ferrari de Andrade L, Tay RE, Pan D, Luoma AM, Ito Y, Badrinath S, et al. Antibody-Mediated Inhibition of MICA and MICB Shedding Promotes NK Cell-Driven Tumor Immunity. Science (2018) 359(6383):1537-42. doi: 10.1126/science.aao0505

128. da Silva IP, Gallois A, Jimenez-Baranda S, Khan S, Anderson AC, Kuchroo VK, et al. Reversal of NK-Cell Exhaustion in Advanced Melanoma by Tim-3 Blockade. Cancer Immunol Res (2014) 2(5):410-22. doi: 10.1158/23266066.Cir-13-0171

129. Zhang Q, Bi J, Zheng X, Chen Y, Wang H, Wu W, et al. Blockade of the Checkpoint Receptor TIGIT Prevents NK Cell Exhaustion and Elicits Potent Anti-Tumor Immunity. Nat Immunol (2018) 19(7):723-32. doi: 10.1038/ s41590-018-0132-0

130. Benson DM Jr, Hofmeister CC, Padmanabhan S, Suvannasankha A, Jagannath S, Abonour R, et al. A Phase 1 Trial of the Anti-KIR Antibody IPH2101 in Patients With Relapsed/Refractory Multiple Myeloma. Blood (2012) 120(22):4324-33. doi: 10.1182/blood-2012-06-438028

131. Wang W, Erbe AK, Hank JA, Morris ZS, Sondel PM. NK Cell-Mediated Antibody-Dependent Cellular Cytotoxicity in Cancer Immunotherapy. Front Immunol (2015) 6:368. doi: 10.3389/fimmu.2015.00368

132. Zhou Z, Li M. Evaluation of BRCA1 and BRCA2 as Indicators of Response to Immune Checkpoint Inhibitors. JAMA Netw Open (2021) 4(5):e217728. doi: 10.1001/jamanetworkopen.2021.7728

133. Parham P. MHC Class I Molecules and KIRs in Human History, Health and Survival. Nat Rev Immunol (2005) 5(3):201-14. doi: 10.1038/nri1570

134. Martín-Fontecha A, Thomsen LL, Brett S, Gerard C, Lipp M, Lanzavecchia A, et al. Induced Recruitment of NK Cells to Lymph Nodes Provides IFNGamma for T(H)1 Priming. Nat Immunol (2004) 5(12):1260-5. doi: 10.1038/ ni1138

135. Mocikat R, Braumüller H, Gumy A, Egeter O, Ziegler H, Reusch U, et al. Natural Killer Cells Activated by MHC Class I(low) Targets Prime Dendritic Cells to Induce Protective CD8 T Cell Responses. Immunity (2003) 19 (4):561-9. doi: 10.1016/s1074-7613(03)00264-4

136. Adam C, King S, Allgeier T, Braumüller H, Lüking C, Mysliwietz J, et al. DCNK Cell Cross Talk as a Novel CD4+ T-Cell-Independent Pathway for Antitumor CTL Induction. Blood (2005) 106(1):338-44. doi: 10.1182/blood2004-09-3775

137. Krebs P, Barnes MJ, Lampe K, Whitley K, Bahjat KS, Beutler B, et al. NKCell-Mediated Killing of Target Cells Triggers Robust Antigen-Specific T-
Cell-Mediated and Humoral Responses. Blood (2009) 113(26):6593-602. doi: 10.1182/blood-2009-01-201467

138. Cook KD, Whitmire JK. The Depletion of NK Cells Prevents T Cell Exhaustion to Efficiently Control Disseminating Virus Infection. J Immunol (2013) 190(2):641-9. doi: 10.4049/jimmunol.1202448

139. Andrews DM, Estcourt MJ, Andoniou CE, Wikstrom ME, Khong A, Voigt V, et al. Innate Immunity Defines the Capacity of Antiviral T Cells to Limit Persistent Infection. J Exp Med (2010) 207(6):1333-43. doi: 10.1084/ jem.20091193

140. Parihar R, Rivas C, Huynh M, Omer B, Lapteva N, Metelitsa LS, et al. NK Cells Expressing a Chimeric Activating Receptor Eliminate MDSCs and Rescue Impaired CAR-T Cell Activity Against Solid Tumors. Cancer Immunol Res (2019) 7(3):363-75. doi: 10.1158/2326-6066.Cir-18-0572

141. Brown CE, Alizadeh D, Starr R, Weng L, Wagner JR, Naranjo A, et al. Regression of Glioblastoma After Chimeric Antigen Receptor T-Cell Therapy. N Engl J Med (2016) 375(26):2561-9. doi: 10.1056/ NEJMoa1610497

142. Ahmed N, Brawley V, Hegde M, Bielamowicz K, Kalra M, Landi D, et al. HER2-Specific Chimeric Antigen Receptor-Modified Virus-Specific T Cells for Progressive Glioblastoma: A Phase 1 Dose-Escalation Trial. JAMA Oncol (2017) 3(8):1094-101. doi: 10.1001/jamaoncol.2017.0184

143. O’Rourke DM, Nasrallah MP, Desai A, Melenhorst JJ, Mansfield K, Morrissette JJD, et al. A Single Dose of Peripherally Infused EGFRvIIIDirected CAR T Cells Mediates Antigen Loss and Induces Adaptive Resistance in Patients With Recurrent Glioblastoma. Sci Transl Med (2017) 9(399):eaaa0984. doi: 10.1126/scitranslmed.aaa0984

144. Chen X, Han J, Chu J, Zhang L, Zhang J, Chen C, et al. A Combinational Therapy of EGFR-CAR NK Cells and Oncolytic Herpes Simplex Virus 1 for Breast Cancer Brain Metastases. Oncotarget (2016) 7(19):27764-77. doi: 10.18632/oncotarget. 8526

145. Ma R, Lu T, Li Z, Teng KY, Mansour AG, Yu M, et al. An Oncolytic Virus Expressing Il15/Il15r $\alpha$ Combined With Off-The-Shelf EGFR-CAR NK Cells Targets Glioblastoma. Cancer Res (2021) 81(13):3635-48. doi: 10.1158/00085472.Can-21-0035

Conflict of Interest: The authors declare that the research was conducted in the absence of any commercial or financial relationships that could be construed as a potential conflict of interest.

Publisher's Note: All claims expressed in this article are solely those of the authors and do not necessarily represent those of their affiliated organizations, or those of the publisher, the editors and the reviewers. Any product that may be evaluated in this article, or claim that may be made by its manufacturer, is not guaranteed or endorsed by the publisher.

Copyright $\odot 2021$ Pan, Zhai, Li, Jiang and Zhang. This is an open-access article distributed under the terms of the Creative Commons Attribution License (CC BY). The use, distribution or reproduction in other forums is permitted, provided the original author(s) and the copyright owner(s) are credited and that the original publication in this journal is cited, in accordance with accepted academic practice. No use, distribution or reproduction is permitted which does not comply with these terms. 